\title{
Do Rhinoceros Auklet, Cerorhinca monocerata, Fledglings Fly to the Sea from Their Natal Burrows?
}

\author{
JAmes L. HaYward and Jere K. Clayburn \\ Biology Department, Andrews University, Berrien Springs, Michigan 49104-0410 USA
}

Hayward, James L., and Jere K. Clayburn. 2004. Do Rhinoceros Auklet, Cerorhinca moncerata, fledglings fly to the sea from their natal burrows? Canadian Field-Naturalist 118(4): 615-617.

The mode of departure of Rhinoceros Auklet fledglings from their nest burrows has remained uncertain. Both walk-down and fly-down hypotheses have been proposed. Here we use the unique geography of Protection Island, Washington, to evaluate the fly-down hypothesis. Some fledglings raised on Protection Island do appear to walk to the water, but our results suggest that many of the island's fledgling Rhinoceros Auklets fly to the sea.

Key Words: Rhinoceros Auklet, Cerorhinca monocerata, fledgling departure, Washington.

Rhinoceros Auklets (Cerorhinca monocerata) are the most abundant puffins in the waters of the Pacific Northwest. Unlike Tufted and Horned puffins (Fratercula cirrhata and $F$. corniculata, respectively), which also breed along western North America, members of most populations of Rhinoceros Auklets leave their nesting colonies before dawn to feed and return after sunset (Wilson and Manuwal 1986; but see Thoresen 1980). Consequently, some basic information on the behavior of these birds remains obscure, despite growing knowledge of their breeding biology (Richardson 1961; Scott et al. 1974; Leschner 1976; Summers and Drent 1979; Vermeer 1978, 1979, 1980; Thoresen 1980, 1983; Wilson and Manuwal 1986; Wilson 1993; Gaston and Duchesne 1996).

One elusive piece of information involves the mode of departure from nest sites by newly-fledged Rhinoceros Auklets. Young Atlantic Puffins (F. arctica) walk, flutter, or fly to the water from their burrows (Lockley 1934; Richardson 1961; Gaston and Jones 1998), whereas fledgling Cassin's Auklets (Ptychoramphus aleuticus) fly to the sea after making short "practice flights" (Manuwal 1974). Leschner (1976) found Rhinoceros Auklet fledglings that were too small to fly "crouched under rocks or crevices in the morning" on Destruction Island, Washington; this suggested to her "that fledglings walk or flutter to the water." Similarly, Wilson (1977) observed fledgling Rhinoceros Auklets on Protection Island, Washington, "walking down the grass covered slopes" to the sea. But Richardson, (1961) who also worked on Protection Island, wrote that "flight [capability] ... appears to develop precociously," and that like the "half-grown young" of murres, fledgling Rhinoceros Auklets "fly down to the water."

On Protection Island, hundreds of Rhinoceros Auklets nest along a sandy cliff that rises above Violet Point, a gravel spit that contains a large Glaucous-winged Gull (Larus glaucescens) colony. Each summer, scores of auklet fledglings are found dead within a relatively defined area of the gull colony, across an artificial channel and marina from the cliff. The distribution of dead fledglings and the unique semi-natural geography of Protection Island allowed us to evaluate Richardson's fly-down hypothesis.

\section{Methods}

Protection Island, Jefferson County, Washington $\left(48^{\circ} 08^{\prime} \mathrm{N}, 122^{\circ} 55^{\prime} \mathrm{W}\right)$, consists of a 35-76-m high plateau surrounded by steep, grass-covered, sandy cliffs ideally suited for Rhinoceros Auklet burrowing. The largest Rhinoceros Auklet colony in Washington is located here, with approximately 27549 burrows (Wilson and Manuwal 1986). Violet Point, a gravel spit that extends $800 \mathrm{~m}$ east from the upper island, contained around 5100 of Glaucous-winged Gull nests during this study (J. G. Galusha, personal communication).

In July and August 1992, 1993, and 1997 the location of each auklet fledgling found dead on Violet Point was plotted by measuring its north or south distance from a transect that measured its eastward distance from the base of the island's east-facing cliff. To estimate age at death, culmen and tarsal lengths, if still present, were measured in 1992 and 1993. The height of the highest $(60 \mathrm{~m})$ nesting burrows on the cliff in relation to the distribution of dead fledglings on Violet Point was used to approximate a range of presumed fledgling flight path angles trigonometrically.

\section{Results}

One hundred and twenty-one dead fledglings (43 in 1992, 11 in 1993, and 67 in 1997) were counted between $106 \mathrm{~m}$ east of the cliff base, at the western margin of the gull colony, and $398 \mathrm{~m}$ east of the cliff base, toward the center of the gull colony (Figure 1). The fledglings apparently died as a result of hitting the spit or being attacked by resident gulls. No dead fledglings were found beyond $398 \mathrm{~m}$. The pooled mean $( \pm$ SD here and below) distance of fledgling corpses from the base of the nest cliff was $303 \pm 58.0 \mathrm{~m}(n=54$, range $=$ $106-398 \mathrm{~m})$. Mean culmen length was $24.4 \pm 3.0 \mathrm{~mm}$ $(n=35)$, and mean tarsus length was $37.9 \pm 1.6 \mathrm{~mm}$ ( $n=48$ ); Rhinoceros Auklets of this size are about 45 days old (Wilson and Manuwal 1986). During late July and early August, we occasionally found live 
Rhinoceros Auklet fledglings hiding in grass between the nesting cliff and the channel/marina, and we regularly observed fledglings swimming in the water of the marina/channel.

\section{Discussion}

Large numbers of dead fledglings found in gull territories east of the marina/channel water and across from the nesting cliff support the hypothesis that these fledglings flew down and over the water from their natal burrows. Alternate means of reaching the east side of the marina/channel were highly unlikely: (1) walk/flutter down slope, enter the marina/channel water from the west shore, leave the water on the east shore, enter the gull colony, be killed; (2) walk/flutter down slope, enter the colony north of the marina/ channel, walk/flutter through a gauntlet of gull territories to the east side of the water, be killed; (3) walk/ flutter down slope, enter the colony north of the marina/channel, be killed, then be transported to distant points east of the water by gulls. With respect to (3), it should be noted that fledging Rhinoceros Auklets exhibit an average mass of $360 \mathrm{~g}$ (Wilson and Manuwal 1986), 34\% of the average mass of $1051 \mathrm{~g}$ (Vermeer 1963) for adult Glaucous-winged Gulls in this region; thus it appears unlikely that auklet corpses could be moved very far from the place where they were killed.

Our data, with those of Richardson (1961), Leschner (1976), Wilson (1977), and Wilson and Manuwal (1986), support the following scenario for the departure of fledgling Rhinoceros Auklets from their nest burrows on Protection Island: In late July and early August, some fledgling auklets walk and flutter, but also many fly directly away from their natal burrows. Fledglings cannot sustain prolonged flight, however, and from the highest nests lose altitude at a rate of $13-32 \mathrm{~m} / 100-\mathrm{m}$ distance, with a slope of $7^{\circ}-18^{\circ}$ (Figure 1B); fledgling flights from lower burrows would exhibit progressively shallower angles. Fledglings from preferred nest sites located directly above the ocean (Richardson 1961) reach the water successfully. Fledglings that fly from nest sites along the cliff above Violet Point hit the gull colony where they are killed, unless they veer to the ocean or are fortunate enough to land in the marina/channel. Whether this scenario applies to fledgling departures at other Rhinoceros Auklet colonies remains unknown.

\section{Acknowledgments}

We thank Robert Edens, Jean Takekawa and Kevin Ryan for permission to work on Protection Island National Wildlife Refuge, Ulrich Wilson for valuable discussions about Rhinoceros Auklets, Shandelle Henson for comments on the manuscript, and Walla Walla College Marine Station for logistical support during this study. Funding was provided by faculty grants to JLH from Andrews University.
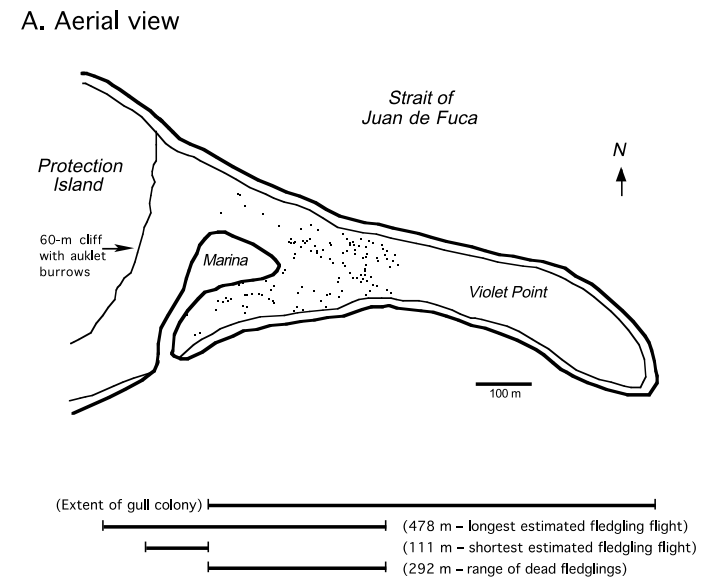

B. Side view

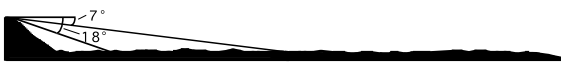

Figure 1. A. Aerial view of Violet Point, Protection Island, Washington. Dots indicate locations of dead fledgling Rhinoceros Auklets found during July and August, 1992, 1993, and 1997. Lines below indicate approximate extent of the spit occupied by the gull colony, extent of fledgling auklet corpses, and estimated extents of fledgling auklet flight distances. B. Side view of Violet Point showing the estimated range of Rhinoceros Auklet fledgling flight paths, sloping from $7^{\circ}-18^{\circ}$ from the highest $(60 \mathrm{~m})$ natal burrows above the gull colony; fledgling flights from lower burrows would exhibit progressively shallower angles.

\section{Literature Cited}

Gaston, A. J., and S. B. C. Dechesne. 1996. Rhincoceros Auklet: Cerorhinca monocerata. The Birds of North America (212). American Ornithologists' Union, Washington, D. C., and Academy of Natural Sciences, Philadelphia, Pennsylvania. 20 pages.

Gaston, A. J., and I. L. Jones. 1998. The Auks: Alcidae. Oxford University Press, Oxford. 349 pages.

Leschner, L. L. 1976. The breeding biology of the Rhinoceros Auklet on Destruction Island. M.S. thesis, University of Washington, Seattle. 77 pages.

Lockley, R. M. 1934. On the breeding habits of the puffin: With special reference to its incubation and fledgling periods. British Birds 27: 214-223.

Manuwal, D. A. 1974. The natural history of Cassin's Auklet (Ptychoramphus aleuticus). Condor 76: 421-431.

Richardson, F. 1961. Breeding biology of the Rhinoceros Auklet on Protection Island, Washington. Condor 63: 456473.

Scott, J. M., W. Hoffman, D. Ainley, and C. F. Zeillemaker. 1974. Range expansion and activity patterns in Rhinoceros Auklets. Western Birds 5: 13-20.

Summers, K. R., and R. H. Drent. 1979. Breeding biology and twinning experiments of Rhinoceros Auklets on Cleland Island, British Columbia. Murrelet 60: 16-22. 
Thoresen, A. C. 1980. Diurnal land visitations by Rhinoceros Auklets. Western Birds 11: 154.

Thoresen, A. C. 1983. Diurnal activity and social displays of Rhinoceros Auklets on Teuri Island, Japan. Condor 85: 373375.

Vermeer, K. 1963. The breeding ecology of the Glaucouswinged Gull (Larus glaucescens) on Mandarte Island, B. C. Occasional Papers of the British Columbia Provincial Museum Number 13. 104 pages.

Vermeer, K. 1978. Extensive reproductive failure of Rhinoceros Auklets and Tufted Puffins. Ibis 120: 112.

Vermeer, K. 1979. Nesting requirements, food and breeding distribution of Rhinoceros Auklets, Cerorhinca monocerata, and Tufted Puffins, Lunda cirrhata. Ardea 67: 101110 .
Vermeer, K. 1980. The importance of timing and type of prey to reproductive success of Rhinoceros Auklets Cerorhinca monocerata. Ibis 122: 342-350.

Wilson, U. W. 1977. A study of the biology of the Rhinoceros Auklet on Protection Island, Washington. M.S. thesis, University of Washington, Seattle. 98 pages.

Wilson, U. W. 1993. Rhinoceros Auklet burrow use, breeding success, and chick growth: Gull-free vs. gull-occupied habitat. Journal of Field Ornithology 64: 256-261.

Wilson, U. W., and D. A. Manuwal. 1986. Breeding biology of the Rhinoceros Auklet in Washington. Condor 88: 143156.

Received 6 February 2004

Accepted 25 October 2004 